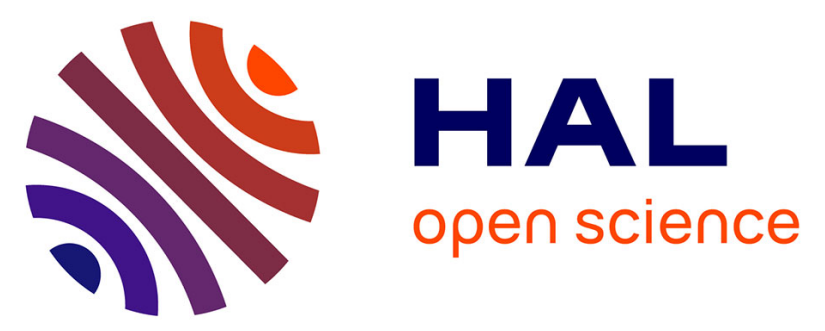

\title{
Sustainable urban development through a blue and green network approach focusing the protection of water resources: the case of the Belo Horizonte Metropolitan Region, in Brazil
}

Nilo Nascimento, Julian Eleuterio, Heloisa Costa, Vinçon-Leite Brigitte, Ana Mourao, Diomira Faria, Roberto Monte Mór

\section{To cite this version:}

Nilo Nascimento, Julian Eleuterio, Heloisa Costa, Vinçon-Leite Brigitte, Ana Mourao, et al.. Sustainable urban development through a blue and green network approach focusing the protection of water resources: the case of the Belo Horizonte Metropolitan Region, in Brazil. International Journal of Water, 2019, 13 (4), pp.311-332. 10.1504/IJW.2019.106045 . hal-02883466

\section{HAL Id: hal-02883466 \\ https: / hal-enpc.archives-ouvertes.fr/hal-02883466}

Submitted on 29 Jun 2020

HAL is a multi-disciplinary open access archive for the deposit and dissemination of scientific research documents, whether they are published or not. The documents may come from teaching and research institutions in France or abroad, or from public or private research centers.
L'archive ouverte pluridisciplinaire HAL, est destinée au dépôt et à la diffusion de documents scientifiques de niveau recherche, publiés ou non, émanant des établissements d'enseignement et de recherche français ou étrangers, des laboratoires publics ou privés. 


\title{
To cite this paper
}

Nascimento, N., Eleutério, J., Costa, H., Vinçon Leite, B., Mourão, A., Faria, D., Monte-Mór, R.M., 2019. Sustainable urban development through a blue and green network approach focusing the protection of water resources: the case of the Belo Horizonte Metropolitan Region, in Brazil. IJW 13, 311.

https://doi.org/10.1504/IJW.2019.106045

\section{Sustainable urban development through a blue and green network approach focusing the protection of water resources: the case of the Belo Horizonte Metropolitan Region, in Brazil}

\author{
Nilo NASCIMENTO*a, Julian ELEUTÉRIO ${ }^{b}$, Heloisa COSTA ${ }^{c}$, Brigitte VINÇON-LEITEd ${ }^{d}$, Ana MOURÃOe , Diomira \\ FARIA ${ }^{f}$, Roberto MONTE-MÓR ${ }^{g}$
}

\begin{abstract}
This paper explores the potentialities offered by blue green approaches to promote protection of water resources at metropolitan scale and to contribute to structuring territorial development. An on-going experience of regional planning and land use regulation in the Belo Horizonte Metropolitan Region (BHMR), in Brazil, is here a reference. With a population of 5.8 million inhabitants and territory of $10,000 \mathrm{~km}^{2}$, the BHMR offers a rich example of land use diversity that highlights the complexity of metropolitan territorial planning and management. In the first part of the paper, blue-green concepts are developed emphasizing their role for the protection of water resources. This is followed by the methods and results of applying these concepts to the BHMR. We then evaluate whether blue green approaches are sufficient to protect water resources and discuss the potentialities of additional tools such as the payment for environmental services with the same objectives.
\end{abstract}

Keywords: metropolitan areas, water resource protection, metropolitan development planning, blue and green approach, metropolitan zoning, participatory process, participatory planning, drinking water supply, sources of drinking water, green corridors

\section{Introduction}

In metropolitan areas, planning and governance issues are increasingly complex and intertwined at multiple territorial, administrative and regulatory levels. To tackle this complexity, a regional scale of planning is necessary for integrating these policies in an effective framework (e.g.: Kelly-Quinn et al., 2014). This is particularly the case of water resources. Sustainability of water resources is a strategic concern for urban development, mainly regarding the provision of safe and affordable drinking water. However, in metropolitan catchments, water bodies are severely impacted by multiple anthropogenic pressures. In order to mitigate these impacts, conservation actions must be, on the one hand, planned at the metropolitan scale and, on the other hand, implemented at the catchment scale. Among conservation measures, those based on blue-green approaches are increasingly considered as effective options.

*a Corresponding author. Professor, Federal University of Minas Gerais, School of Engineering, Av. Antônio Carlos, 6627, BI. 1, Room 4508, Belo Horizonte, MG, 31270-901, Brazil. E-mail address: niloon@ehr.ufmg.br or niloon2012@gmail.com Phone: +55.31.3409.1872, Fax: +55.31.3409.1001.

${ }^{\mathrm{b}}$ Assistant professor, Federal University of Minas Gerais, School of Engineering, Av. Antônio Carlos, 6627, Bl. 1, Belo Horizonte, MG, 31270-901, Brazil.

c Professor, Federal University of Minas Gerais, Institute of Geosciences, Av. Antônio Carlos, 6627, Belo Horizonte, MG, 31270-901, Brazil.

d Researcher, École des Ponts ParisTech, LEESU, 6-8 avenue Blaise Pascal, Cité Descartes, Champs sur Marne, 77455 Marne-la-Vallée Cedex 2, France.

e Graduate student, Federal University of Minas Gerais, Institute of Geosciences, Av. Antônio Carlos, 6627, Belo Horizonte, MG, 31270-901, Brazil.

${ }^{f}$ Assistant Professor, Federal University of Minas Gerais, Institute of Geosciences, Av. Antônio Carlos, 6627, Belo Horizonte, MG, 31270-901, Brazil.

g Associate Professor, Federal University of Minas Gerais, Centre for Development and Regional Planning, Av. Antônio Carlos, 6627, Belo Horizonte, MG, 31270-901, Brazil. 
This paper focuses on the potentialities offered by blue-green approaches for protecting water resources at a metropolitan scale. It also includes a discussion on the role of blue-green strategies in structuring territorial development as well as in contributing to an equitable use of and access to natural resources at the metropolitan scale, through collaboration among municipalities (local public authorities), the state government (provincial public authority), stakeholders, end users and metropolitan citizens. These core issues of managing natural resources at the metropolitan scale are herein exemplified and discussed based on an experience of large scale planning and regional land use regulation in the Belo Horizonte Metropolitan Region (BHMR), located in southeast Brazil (Figure 1).

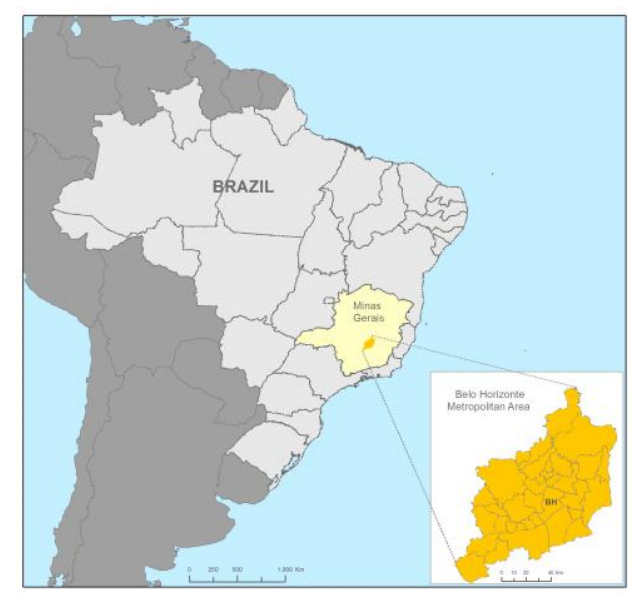

Figure 1. Location of the Belo Horizonte Metropolitan Region, in southeast Brazil.

With a population of 5.8 million inhabitants (IBGE, 2014), territory of nearly $10,000 \mathrm{~km}^{2}$ and including 34 municipalities, the BHMR offers a rich example of land use diversity that highlights the immense complexity of metropolitan territorial planning and management (UFMG, PUC Minas, UEMG, 2011). The BHMR is experiencing a process of regional planning and institutional development for metropolitan management since the beginning of 2009, which may be considered advanced in relation to similar initiatives in Brazil and other emerging economies. This is particularly relevant in Brazil where there is a process of transferring political responsibilities to local administrative spheres, which started with the end of the dictatorship in the mid 1980's. Public participation in political decisions has been rebuilt since then resulting in important efforts to consolidate the development of public policies and management of resources and public services at regional scale, particularly the metropolitan scale. Brazil is a federal republic with three government levels: the municipalities, the states and the federal government.

In the BHMR, a collaborative process involving the Minas Gerais state government (MGSG, provincial level), the BHMR 34 municipalities and civil society representatives led to the establishment of a metropolitan governance framework which includes two public policy formulating and evaluating committees: the Metropolitan Assembly (MA) which includes representatives of the MGSG, the civil society and all 34 municipalities, and the Deliberating Committee for Metropolitan Development (DCMD) which includes representatives of the most populated and contiguous municipalities, the MGSG and the civil society. An executive organ, called the Metropolitan Agency (BHMR-A), oversees the development of technical studies and public policy implementation. These institutions are currently leading the metropolitan planning process, which started in 2009 with the development of the Metropolitan Plan for Integrated Development (PDDI), which continued with the development of a Macrozoning Project (UFMG, 2015) and presently with the revision of BHMR municipal Master Plans. The Metropolitan Fund, financed by municipalities and MGSG contributions, ensures the required financial resources for PDDI implementation and the BHMR management.

In the PDDI, two policy implementation strategies are particularly relevant for natural resource management, the land use regulating tool called ZIM (Zone of Metropolitan Interest) and the blue-green framework called TVA ("Trama Verde e Azul", meaning blue-green network). ZIMs are territorial units recognised as expressing 
functions of metropolitan public interest. They were identified through a comprehensive participatory process and will be legally stated through their territorial delimitation and associated land use parameters aiming to achieve specific objectives such as limiting the partition of the territory (e.g. minimum lot area), restricting the increase of impervious surfaces (e.g. minimum pervious surface to be maintained in each lot), controlling population density (e.g. maximum number of housing units per building), increasing vegetation cover and the presence of trees in urban space (e.g. minimum front retreat in each lot), establishing social housing development areas (e.g. percentage of social housing in each new development), etc. Therefore, ZIMs are zoning instruments (e.g. Bernstein, 1993) requiring technical and political justifications based on their metropolitan functions. These functions are the expression of the objectives and guidance emanating from the PDDI and from the specific participatory process of ZIM identification and justification. The ZIM tool implies shared land use regulation between local authorities and the MGSG through the metropolitan governance framework previously described.

Regarding the blue-green approach in the BHRM regional planning, it was first inspired by the concept of "Trame Verte et Bleue" (TVB, acronym in French) adopted in France, particularly the experience of the TVB implementation in the Nord-Pas-de-Calais region (Vimal et al, 2012). The Nord-Pas-de-Calais is a brother region to the state of $M G$ and the cooperation between both provinces facilitated this transfer of experiences during the PDDI preparation. Regarding the design of the TVA for the BHMR, concepts of low impact development (LID), water sensitive urban design (WSUD) and green infrastructure (Romnée et al, 2015; Certu, 2008; Rouse and Bunster-Ossa, 2013; Fletcher et al, 2015; Farr, 2008) were added due to the relevance of these approaches in urban water management.

In the present paper we present and discuss the ZIM and TVA approaches with a focus on the protection of water resources and water management in the BHMR territory. In the first part of the paper we describe the ZIM and TVA concepts, objectives and methods. We then present how they can be combined with the purpose of improving the protection of catchments which are relevant for drinking water supply at metropolitan scale. In the paper discussion section, we evaluate whether these two approaches are sufficient to provide water resource protection and briefly discuss the potentialities offered by additional tools such as paying for ecosystem services.

\section{Methodology for developing the ZIM and TVA in the BHMR}

\subsection{The PDDI as a guidance for the ZIM and TVA development}

Four transversal thematic axes oriented the PDDI development: (i) accessibility, encompassing integrated policies for transport and mobility, housing, health, social assistance and digital democracy; (ii) security, encompassing integrated policies for public security, environmental risks, climate change mitigation, food security, capacity building and small scale production; (iii) sustainability, gathering policies on mining territories, water resources and sanitation, solid waste management, identification and recovery of protected areas, low carbon economy and compensation for ecosystem services; and (iv) urbanity with policies for public space democratisation, landscape management and cultural values, territorial management for education and culture, and culture funding.

The ZIM and TVA approaches allowed for addressing PDDI proposals with a focus on significant BHMR territorial restructuration, from a traditional centre-periphery structure to a "network of multilevel centralities connected by a multimodal mobility infrastructure network" (Monte-Mór et al, 2016).

Among many of its negative consequences, the centre-periphery model leads to a progressive reduction in the offer of work opportunities, public services and commerce in many of the municipalities that are part of the metropolitan region. For many metropolitan citizens this implies long daily journeys to assess work, education, health care, commerce and related services. Other than the environmental implications of energy consumption, pollutant emissions and time involved with many people commuting to and from Belo Horizonte, the costs, offer, performance and lack of comfort of the existing metropolitan transport system 
act as an incentive to use individual transport alternatives and further complicate access to central urban areas for low-income inhabitants. The excessive centrality of the most urbanised areas in a metropolitan region may also be a factor of local social life impoverishment, reducing social interactions and people involvement in the political and cultural life of local communities, as well as preventing the development of a sense of belonging to a metropolitan area.

In parallel, a process of urban scattering is observed in the BHMR because of two main causes. The first is a tendency of high-income families to move to gated neighbourhoods in the outskirts, attracted by a larger provision of ecosystem services and by a perception of security and exclusivity that is expected to be provided by those neighbourhoods. Secondly, urban developers adopt strategies to purchase land in the outskirts of urbanised areas to be developed and commercialised at higher prices in the future. Concomitantly, part of the older urbanised areas is submitted to a process of densification mainly guided by the real estate market, notwithstanding the support capacity of the existing infrastructure, usually obsolete and designed for a much lower population density. Although higher urban density may be a strategy leading to sustainability, if not well-planned this process may result in environmental inefficiencies such as poor wind circulation, heat island formation, high energy consumption for air conditioning, traffic jams and increased flood risks, among other negative impacts (e.g. OECD, 2012; Charlot-Valdieu and Outrequin, 2011; Farr, 2008; Fouchier,1997).

\subsection{The ZIM approach}

The metropolitan restructuring proposal in PDDI resulted in the identification of ZIMs focused on promoting a polycentric interconnected metropolitan network, reinforcing the role of other centralities on the attraction of economic activities, job opportunity offers and provision of public and private services. In parallel, initiatives for identifying local cultural assets and for reinforcing the creativity, cultural and ethnical diversity of the population were associated with the ZIM approach as a way for promoting a sense of metropolitan citizenship and enriching opportunities for social inclusion (Monte-Mór et al, 2016). The ZIM identification was also guided by the initiative of protecting and stimulating agricultural activities relevant to food security, and as a method for preserving rural traditions and opportunities for income generation at the metropolitan area. It also recognized the need to control negative environmental agricultural impacts by evolving to an agroecological farming model, for example (Costa et al, 2015). The protection of green areas with multiple objectives, including catchments which are strategic sources of drinking water, were also part of the objectives and guidance of the ZIM and TVA approaches.

Methods employed for ZIM identification and establishment of ZIM parameters were based on comprehensive technical studies regarding a great diversity of topics, comprising demography, regional economy, environment characteristics, public finances, public service provision, transport, energy and water infrastructure, solid waste management, natural resources assessment, environmental policy and management, municipal urban planning and land use regulation, housing demand and provision, on-going and planned major development projects and others. These technical studies, mainly developed by a team of faculty, researchers and students from the Federal University of Minas Gerais (UFMG) and technical staffs from the municipalities and the MGSG, were associated with expert and popular knowledge resulting from a permanent public participatory process which included a large panel of stakeholders (local elected officials, civil society representatives, non-governmental organisations (NGO), developers, etc). The PDDI involved 3,000 participants representing 610 institutions, over 18 months. In the ZIM and TVA processes, about 1120 participants attended 13 workshops organised in 5 sub-regions of the BHMR and 3 seminars organised in Belo Horizonte as open events.

During the workshops, personal knowledge of local and regional issues perceived as having metropolitan relevance emerged with the support of collaborative mapping, pictures and a system of icons representing topics such as transport, water supply and sanitation, health, security, housing, education, mining, other industrial sectors, open spaces, areas of environmental interest, etc (Figure 2). The results of each phase of the workshops were combined with those of technical studies in the ZIM identification and justification. The ZIM delimitation and associated rationale were discussed and amended during the open Belo Horizonte 
seminars. This process proved to be essential for achieving ZIM proposal coherence and convergence, validating them at the metropolitan scale. It allowed for integrating information and knowledge obtained from literature and databases, results of studies on different fields conducted by experts, government guidance and recommended policies, as well as civil society knowledge and preoccupations. After 18 months of intense work, from December 2013 to June 2015, nineteen ZIMs eventually emerged as having approved and justified metropolitan functions and interest, therefore requiring specific land use regulation (see Figure 3).
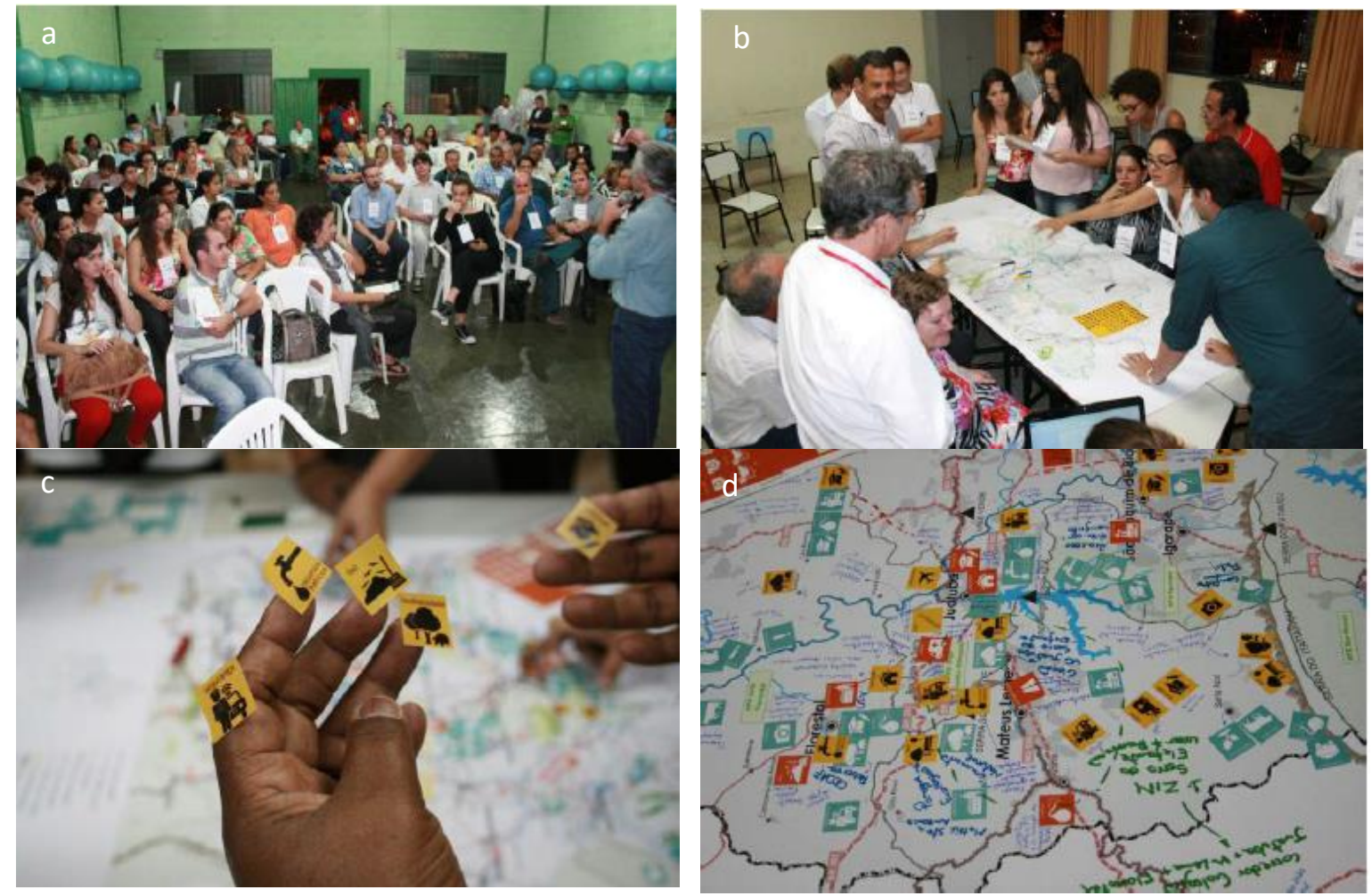

Figure 2. Examples of the ZIM participatory process: a) workshop debates; b) collaborative mapping of the main metropolitan issues; $c$ ) icons representing issues of metropolitan interest; $d$ ) example of a map resulting from the workshops (Source: UFMG, 2015)

In the BHMR, 32 of its 34 municipalities are connected to an integrated metropolitan water supply system which is operated by a joint-stock water utility, called COPASA, which is a company predominantly owned by the state of Minas Gerais. Several water sources provide water for this metropolitan system (Table 1 and Figure 3). Major pipelines connect these water production systems which permit water transfer among them, making the metropolitan water supply system more flexible and safer.

The ZIM Jabuticatubas and ZIM Taquaraçu are water sources to be developed in the future, resulting from a potential increase in the drinking water demand. This is also the case of ZIM Gandarela which has not yet been exploited. It is a subcatchment of the Rio das Velhas river basin where one of the oldest regional drinking water systems is also located. Additionally, Gandarela is a relevant natural and cultural asset. Besides other interests and functions for the BHMR, the ZIM land use regulation of these three areas allows for protecting important water resources for the future, reducing water shortage risks in the region. The ZIM Serras is a long green corridor on the hilltops of the Espinhaço, a complex of mountains located in the south of the BHMR, rich in iron ore and an important water source, landscape and cultural reference. The Rio Paraopeba system was developed in 2015 as an additional water resource to face drought periods. It is only operated during the rainy season to allow for more efficient operation of three reservoirs that are part of the metropolitan drinking water system, the Serra Azul, Manso and Vargem das Flores reservoirs. 
Most of the ZIMs defined as strategic catchments for drinking water are also occupied by relevant agricultural activities, producing mainly fruits and vegetables for the BHMR. In these cases, conflicts are observed regarding the use of water for irrigation and the presence of fertilizers and pesticides which are sources of water contamination. Iron ore mining activities are present in at least three of these catchments, the Velhas river basin and Serra Azul and Manso stream catchments and in the ZIM Serras, leading to conflicts regarding declining water table levels at mining areas, risks associated with tailing dams (dambreak risks), water pollution, landscape deterioration, sediment production, etc. Urban sprawl is observed in ZIMs such as the Serra Azul and Vargem das Flores catchments, frequently involving concerns related to poor solid waste and wastewater management, as well as diffuse pollution during rainfall events.

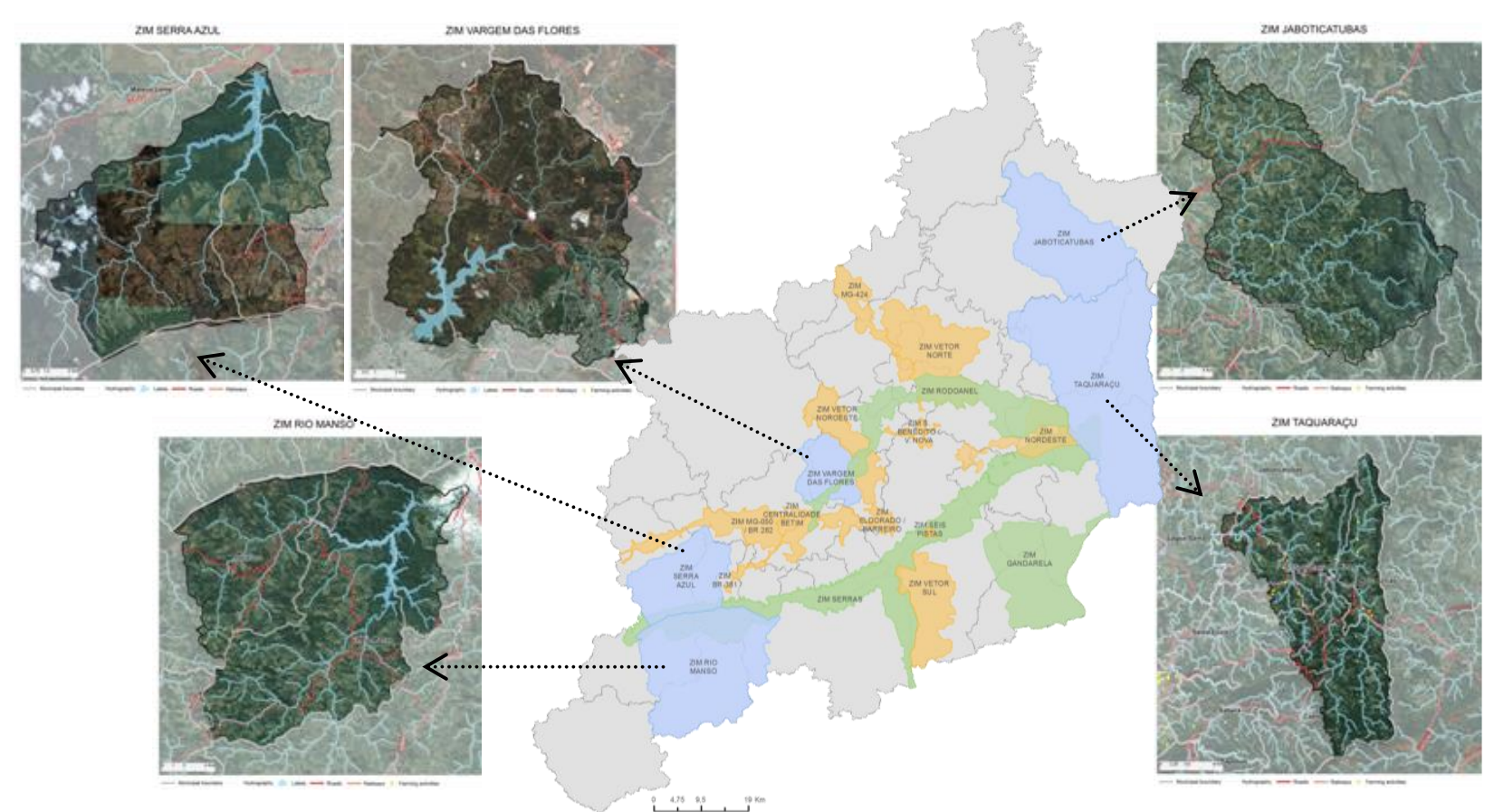

Figure 3. Location of the $19 \mathrm{ZIMs}$ in the BHMR. Highlighted catchments: five ZIMs which are strategic drinking water sources (Source: adapted from UFMG, 2015).

Table 1. BHMR water supply system (Source: updated from Nascimento et al, 2006)

\begin{tabular}{ccc}
\hline Water supply system & Full capacity & ZIM \\
\cline { 2 - 3 } & $\left(\mathrm{m}^{3} / \mathrm{s}\right)$ & Serras \\
\hline Ibirité system & 0.45 & Serras \\
Morro Redondo system & 0.75 & Serras \\
Água Bruta Barreiro system & 0.20 & Serras \\
Água Bruta Catarina system & 0.17 & (Gandarela) \\
Rio das Velhas system & 6.75 & Vargem das Flores \\
Vargem das Flores system & 1.20 & Serra Azul \\
Serra Azul system & 2.60 & Manso \\
Rio Manso system & 4.20 & - \\
Rio Paraopeba system & 5.00 & (Jabuticatubas) \\
Rio Jabuticatubas & to be developed & \\
Rio Taquaraçu system & to be developed & \\
\hline Total & 21.32 &
\end{tabular}

\subsection{The TVA approach}

In 2007, the French government started an innovative process called "Grenelle de l'Environnement", based on a negotiating process including five stakeholder categories (local authorities, state, trade unions, companies and NGOs), seeking to develop a national action plan for environmental management. 
Biodiversity was a key issue in this process and the "Trame Verte et Bleue" (TVB) approach was designed with a focus on biodiversity conservation. The TVB was proposed as a national framework, considered as a "living fabric" of the territory, where ecological continuities seek to support ecosystem functioning. The components of the TVB allow that species fulfil their requirements for nutrition, reproduction, rest, dispersion and migration (Allag-Dhuisme et al., 2010; Vimal et al., 2012).

In the BHMR the TVB was renamed and had its definition enlarged as TVA, an acronym for "Trama Verde e Azul" (green and blue network), conceived as a multifunctional part of the metropolitan territory with significant potential for contributing to its territorial restructuring. The TVA concepts were concomitantly developed with the ZIM approach and under the same participatory process. The main objectives the TVA expected to be fulfilled in the BHMR are:

- Restoring and protecting areas of particular environmental interest at metropolitan scales such as wetlands and riparian areas, natural parks, karstic areas, mountain complexes;

- Reducing natural risks such as flooding and landslides;

- Mitigating environmental impacts of agricultural, industrial and mining activities;

- Mitigating impacts of urbanization on the local climate, as in the case of heat islands, through a considerable increase in the presence of trees and green spaces in urban areas;

- Promoting connectivity (e.g.: green corridors, riparian areas) by integrating urban and protected areas within the metropolitan region;

- Promoting biodiversity by improving the ecological state of urban and metropolitan areas and recovering ecological continuity.

It is important to emphasise that the TVA may play a wide variety of multifunctional roles, where examples include: alternative transport modals such as pedestrian and bike routes, wet weather diffuse pollution abatement, air pollution reduction and heat island effect abatement (McPherson et al, 2005; Rouse and Bunster-Ossa, 2013; Niemelä et al, 2010; Lundy and Wade, 2011). They can also promote biodiversity and create opportunities for leisure and sport activities, and for social contacts and social inclusion in the urban context, depending on their location and characteristics. The TVA can also play an important role in delimiting urban areas, preventing excessive urban sprawl, helping to reinforce lively central locations and contributing to protect agricultural areas and those of cultural assets. In this sense, the TVA can contribute to strengthen the local and metropolitan cultural identity, creating opportunities for urban residents to access the countryside and directly benefit ecosystem services, enriching opportunities for leisure, sports and tourism. This leads to the acquisition of new knowledge and opportunities to socialise with other citizens of the metropolitan sphere. In this sense, the TVA may have a positive impact on social and cultural inclusion, as well as enhanced democracy.

The TVA was also developed using reference to Brazilian experiences such as the Drenurbs programme. The Drenurbs is a Belo Horizonte river restoration program, based on participatory processes and focused on river restoration, flood risk management, housing and low-income neighbourhood recovery, which exemplifies environmental public policies focusing on low-income high-density land use occupation (Costa et al, 2009; Costa et al, 2012; Knauer et al, 2011).

According to the BHMR approach, the first TVA elements were linear, such as creeks, streams and rivers, including their riparian areas, as well as mountain chains exemplified by the ZIM Serras. The legal basis to define these landscape elements as part of the TVA is the Brazilian Forest Code (Federal Law n. 12651/2012, Brazil, 2012) according to which riparian areas, hill and mountain ridges, and steep hillslopes are protected areas where the natural vegetation cover must be preserved. These linear landscapes are by themselves linking elements, and by connecting protected areas and natural reserves, may play an important role in biodiversity protection.

Connections were first established by green corridors among protected areas such as natural parks, reserves, major water bodies (lakes and reservoirs), woods, forests and wetlands. This effort included a detailed analysis of different spatial datasets (vegetation cover, protected areas, hydrography, caves, cultural 
heritage, archaeological sites, agricultural areas, strategic water sources, mining zones, etc) (Figure 4-a). Additional criteria concerned ecological issues such as previously proposed green corridors and the main corridors used by animals in their displacement, for the areas where this information is available (e.g. Jales, 2013). Strategic water resources, such as the ZIMs Serra Azul, Manso and Vargem das Flores were a TVA development target, where a detailed delineation of wetlands, riparian areas and remaining forests was performed to be discussed with stakeholders through the participatory process.

The TVA can also play an important role in flood and land slide risk reduction since it offers an alternative to dense occupation of these risky areas. The social and economic impacts of floods are expected to be lower in green corridors along rivers when compared to densely occupied areas, even if the same concerns of flood risk management are to be considered, particularly if green corridors are located within urban areas. Unfortunately, flood and land slide risk assessments are not available for the entire BHMR, although the mapping of riparian areas and steep slopes, as required by the Forest Code, allowed for integrating them in the TVA planning process even if not with the required precision.

TVA may also play important roles in reducing soil erosion and absorbing sediments and diffuse pollution chemicals (fertilizers, pesticides, heavy metals, organic micropollutants ...) in rural, industrial and urban areas. The TVA rationale in meeting these objectives requires detailed studies based on deep knowledge about site physical characteristics and existing and planned land uses. In the present TVA planning phase, a more detailed effort has been made in the case of catchments which are strategic sources of drinking water (see paragraph 3). Nevertheless, it is recognized that more comprehensive studies and justifications concerning the TVA potential benefits will be required in the future, at its implementing phase.

In the BHMR, two land use categories offer a significant challenge for TVA conceptualisation: (i) the existing densely occupied territories (Belo Horizonte, Contagem, Betim, Sabará and other municipalities which form a continuous urbanised area representing more than $15 \%$ of the metropolitan area); and the (ii) mining territories which are mainly located along the ZIM Serras (Figure 3). These two land use types result in significant territorial discontinuities for TVA implementation.

Particularly in the developing world, urbanisation has frequently been developed according to conventional approaches. This has led to an intense use of grey infrastructure, resulting in highly impervious surface rates, restricting green areas and channelling urban streams to conform to the road system. This is the case in the BHMR where a green retrofit is required to recover the TVA continuity throughout the core densely occupied areas of the metropolitan territory. Concepts of green infrastructure, in close relationship with the TVA's, will be of great interest.

Retrofitting green infrastructure in this constructed environment can potentially be done by increasing tree canopy cover and restoring water bodies such as urban streams, ponds and lakes, implementing urban parks and squares in available open spaces, and adopting a wide variety of urban water management devices derived from LID (low impact development), WSUD (water sensitive urban design), and SuDS (sustainable drainage systems) concepts in the public and possibly private spaces (Nascimento et al, 2016; Romnée et al, 2015; Baek et al, 2015, Meerow and Newell, 2017; Garcia-Cuerva et al, 2018; Zhang and Chui, 2018). This may include rain gardens, green roofs, bioretention, infiltration and water storage devices, and others. A key point in developing this TVA approach is to consider the acceptance of these solutions by citizens and municipal public service officials (e.g. green areas, urban drainage, road system services) (e.g. Bowman and Thompson, 2009, Bowman et al, 2012, Baptiste et al, 2015), an issue that could not be adequately addressed in the ZIM and TVA processes due to the territorial planning scale. Subsequent studies are being developed to better address the potential and benefits of blue-green strategies in the BMRH (e.g. Nascimento et al, 2016).

Regarding iron ore mining, these activities are quite relevant for the BHMR and Minas Gerais state economy. They make up an area denominated the "Quadrilátero Ferrífero" (the Iron Quadrangle) which encompasses part of the metropolitan territory. It also well known that mining activities may cause very negative 
environmental impacts, part of which are irreversible, such as biodiversity and landscape asset losses. To complying with environmental policy requirements mining companies provide compensation by protecting large areas in the Iron Quadrangle which can be integrated in the TVA, even if most are located outside the metropolitan territory. Additionally, the BHMR planning process recommends that mine decommissioning plans include an assessment of the possibility of integrating them in the TVA network.

All data and conceptual analysis and debates that took place during the participatory process led to the delineation of the first proposal for a TVA for the entire BHMR (Figure 4.B).

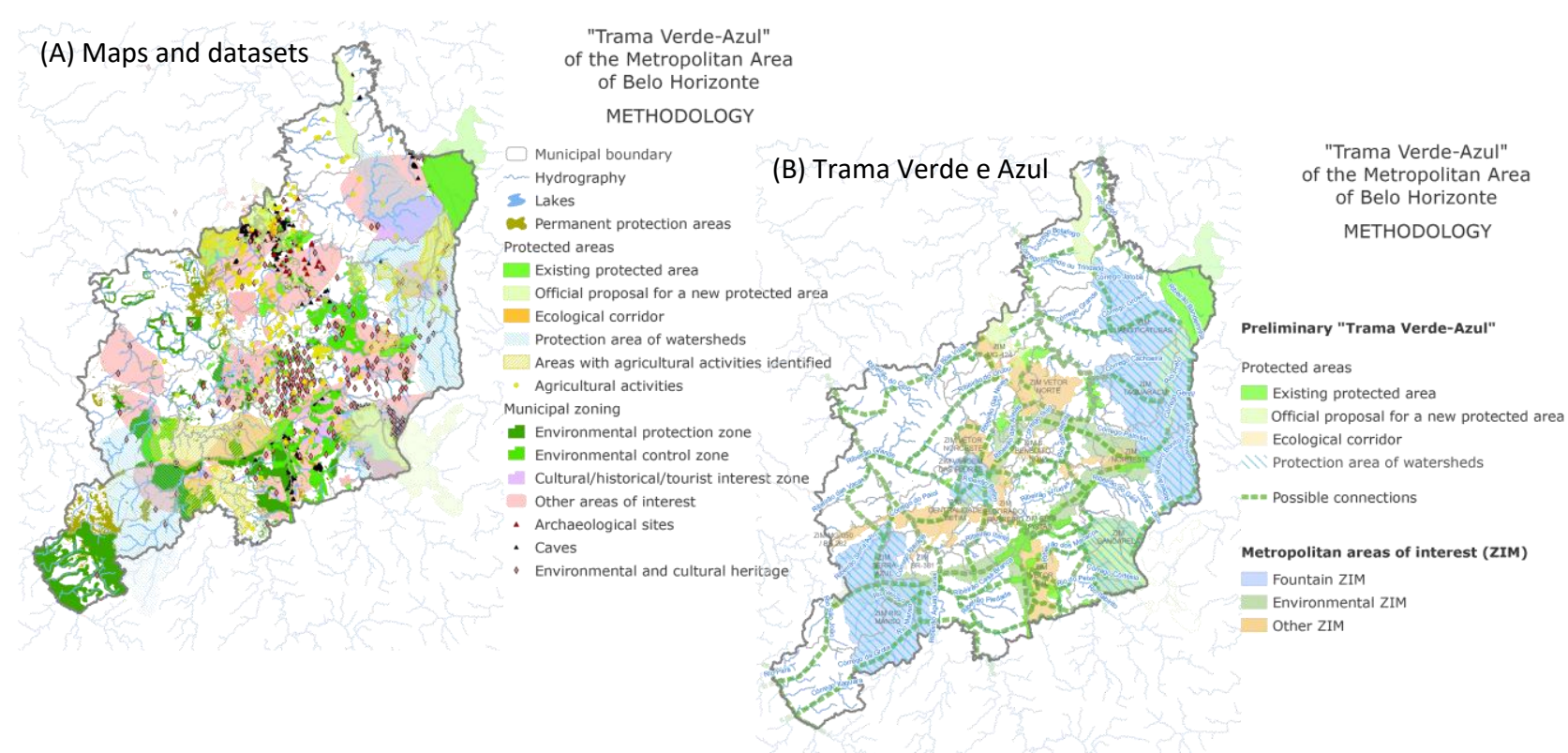

Figure 4. TVA conception in the BHMR: (a) maps and datasets analysed to delineate the TVA; (b) proposition of the TVA for the BHMR, on a regional scale (Source: adapted from UFMG, 2015).

The ZIM and TVA projects are now under evaluation by the Minas Gerais State Assembly to become a metropolitan law. In parallel, the UFMG is assisting the BHMR municipalities in the process of adapting their urban development plans to the PDDI, ZIM and TVA requirements.

\section{Combining ZIM and TVA approaches in drinking water source catchments}

In this section we exemplify the association of the ZIM and TVA approaches for catchments which are strategic drinking water sources. We consider the case of the Serra Azul stream catchment, one of the three water supply systems which are equipped with reservoirs. The existence of the reservoir and the land use diversity in the Serra Azul stream catchment makes it an adequate site for combining the ZIM and TVA approaches.

The Serra Azul stream catchment has a surface of $256 \mathrm{~km}^{2}$ (Figure 5). Due to its role in water supply, the catchment is protected by a specific land use regulation called the "Area de Proteçao Especial", APE (Minas Gerais State Law n. 20792/1980). This environmental protection law, enacted 2 years before the water system operation started, stated that all existing forests in the catchment are strictly protected. It also requires that any urban development project in the catchment be submitted to the simultaneous approval of the MGSG and the municipalities involved. The APE law eventually revealed to be ineffective in protecting the natural forests existing in the Serra Azul catchment (Neves, 2005). In fact, the law does not clearly indicate who is responsible for enforcing it and how it is to be applied. In the absence of an institutional framework to enforce it, the law is essentially of no use.

To protect the reservoir and its surrounding area, COPASA, the water utility which operates the Serra Azul system, acquired an area of $32 \mathrm{~km}^{2}, 12.5 \%$ of the total catchment area, comprising the area occupied by the 
reservoir and the hillslopes that directly contribute to it (Figure 6). In doing so, COPASA sought to avoid the development of illegal occupation and leisure activities along the shore of the reservoir. The COPASA's experience with management of an older reservoir, Vargem das Flores, showed just how difficult it is to control illegal occupation and tourism when relying only on environmental protection legislation (Figure 7).

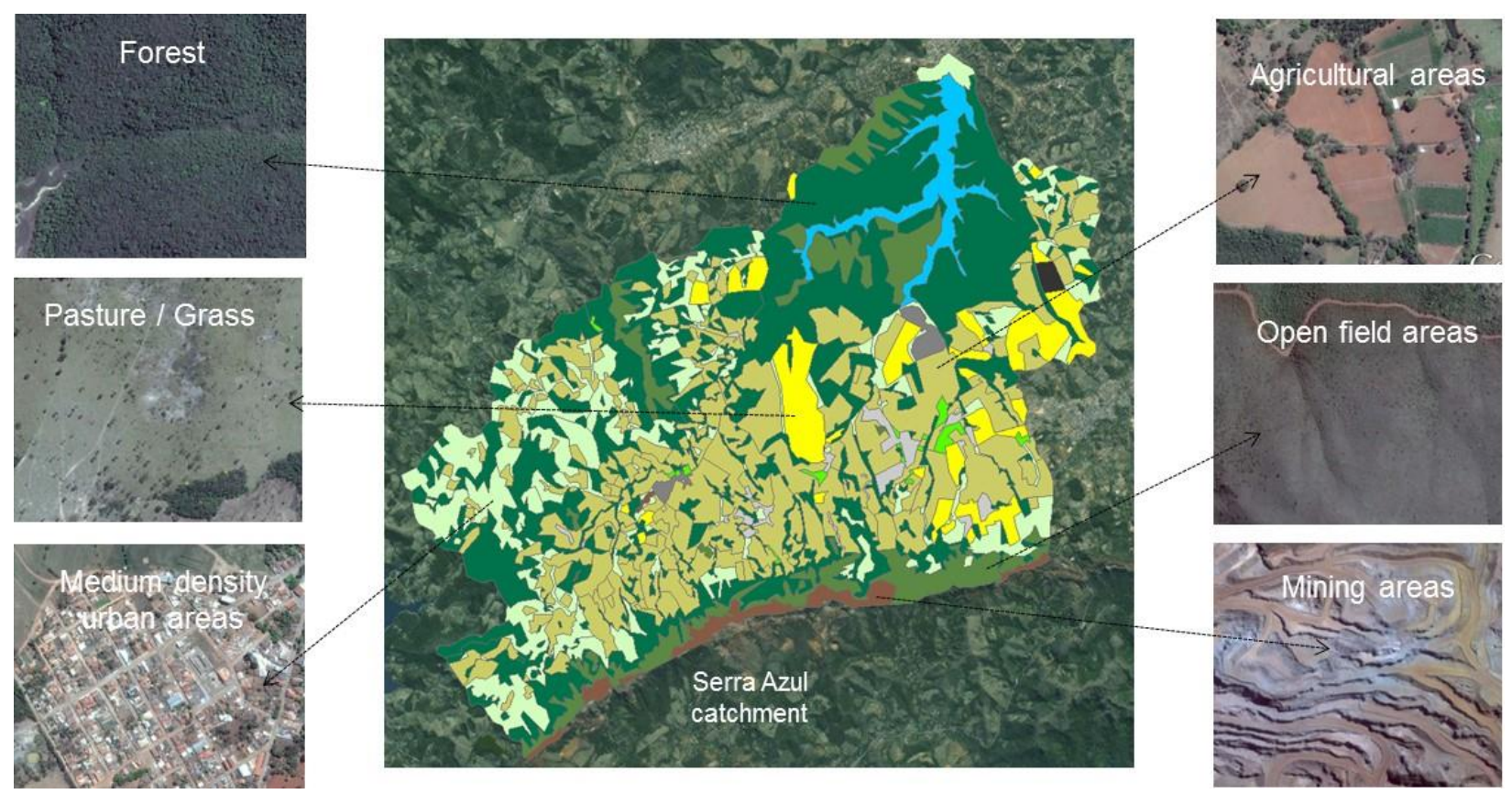

Figure 5. Serra Azul stream catchment and main land uses (Source: adapted from UFMG, 2015).

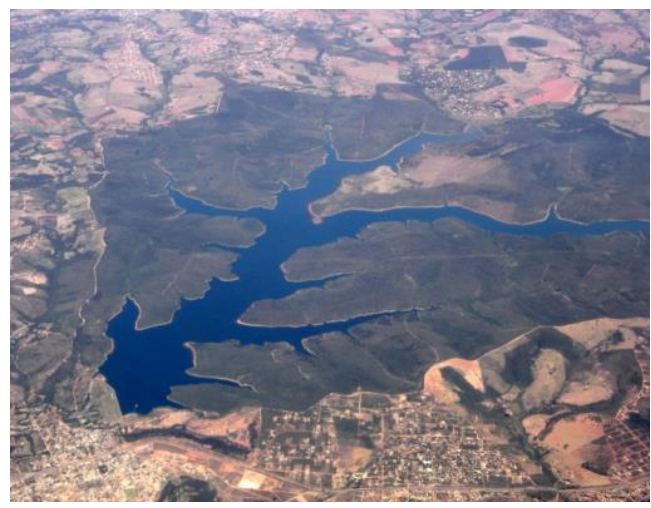

Figure 6. Serra Azul reservoir and associated protected area (Source: http://www.panoramio.com)
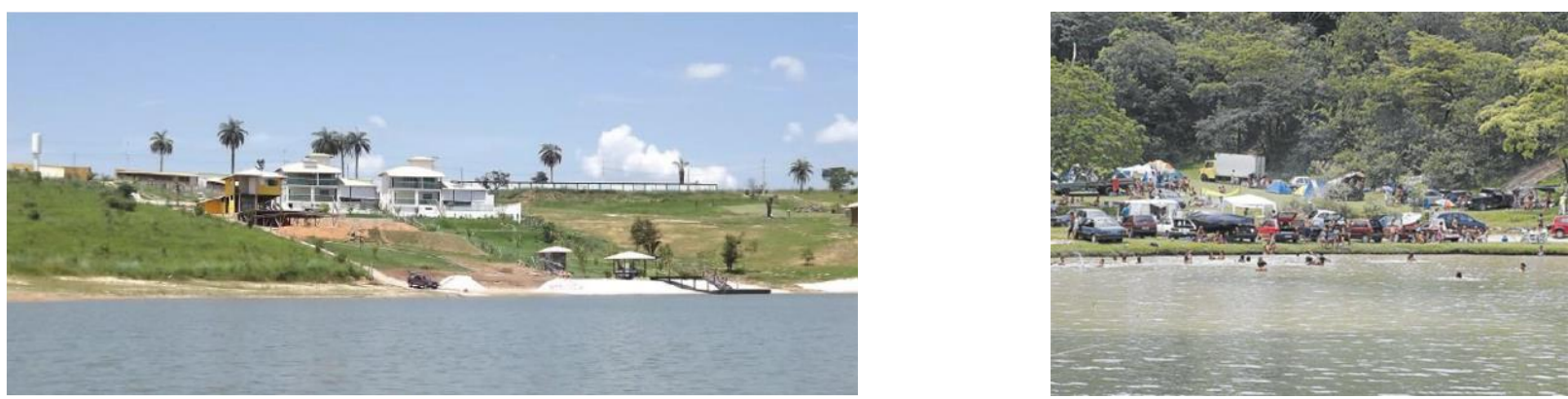

Figure 7. Vargem das Flores reservoir: illegal occupation of protected areas and tourist activities along the shores of the reservoir (Source: Prefeitura de Contagem, 1997) 
The full Serra Azul water production capacity corresponds to about $16 \%$ of the BMRG full capacity, making its protection very relevant for the metropolitan region, which justifies its main ZIM function, in addition to other environmental interests of the area. The ZIM parameters, stated according to the methodology previously described, considers the entire catchment as an environmental protection area with three levels of protection (Figure 8 and Table 2).

Table 2. ZIM description and land use parameters (Source: UFMG, 2015)

\begin{tabular}{|c|c|c|}
\hline Zoning & Description & Land use parameters \\
\hline ZP-1 & $\begin{array}{l}\text { Comprises the area directly contributing to the reservoir, areas protected } \\
\text { by the Forest Code and areas covered by remaining woods and forests. The } \\
\text { purpose of the land use regulation is to keep their status of strictly } \\
\text { protected areas. }\end{array}$ & $\begin{array}{c}\mathrm{BA}=5 \% \\
\mathrm{PS}=95 \%\end{array}$ \\
\hline ZP-2 & $\begin{array}{l}\text { Comprises areas of agricultural production playing important roles of food } \\
\text { security and income generation. Land use regulation seek to avoid urban } \\
\text { sprawl in these areas }\end{array}$ & $\begin{aligned} B A & =10 \% \\
P S & =85 \% \\
M L A & =20,000 m^{2}\end{aligned}$ \\
\hline ZP-3 & $\begin{array}{c}\text { Comprises areas where a process of urban extension already exists. Land } \\
\text { use regulation aims at controlling this process of urban developing, } \\
\text { ensuring environmental quality and low impact. }\end{array}$ & $\begin{aligned} \mathrm{BA} & =50 \% \\
\mathrm{PS} & =80 \% \\
\mathrm{MLA} & =10,000 \mathrm{~m}^{2} \\
\mathrm{MBH} & =9.0 \mathrm{~m}\end{aligned}$ \\
\hline
\end{tabular}

\section{Where:}

BA: maximum building area allowed; as a $\%$ of the lot area

PS: minimum area of pervious surface, as a $\%$ of the lot area

MLA: minimum lot area

$\mathrm{MBH}$ : maximum building height

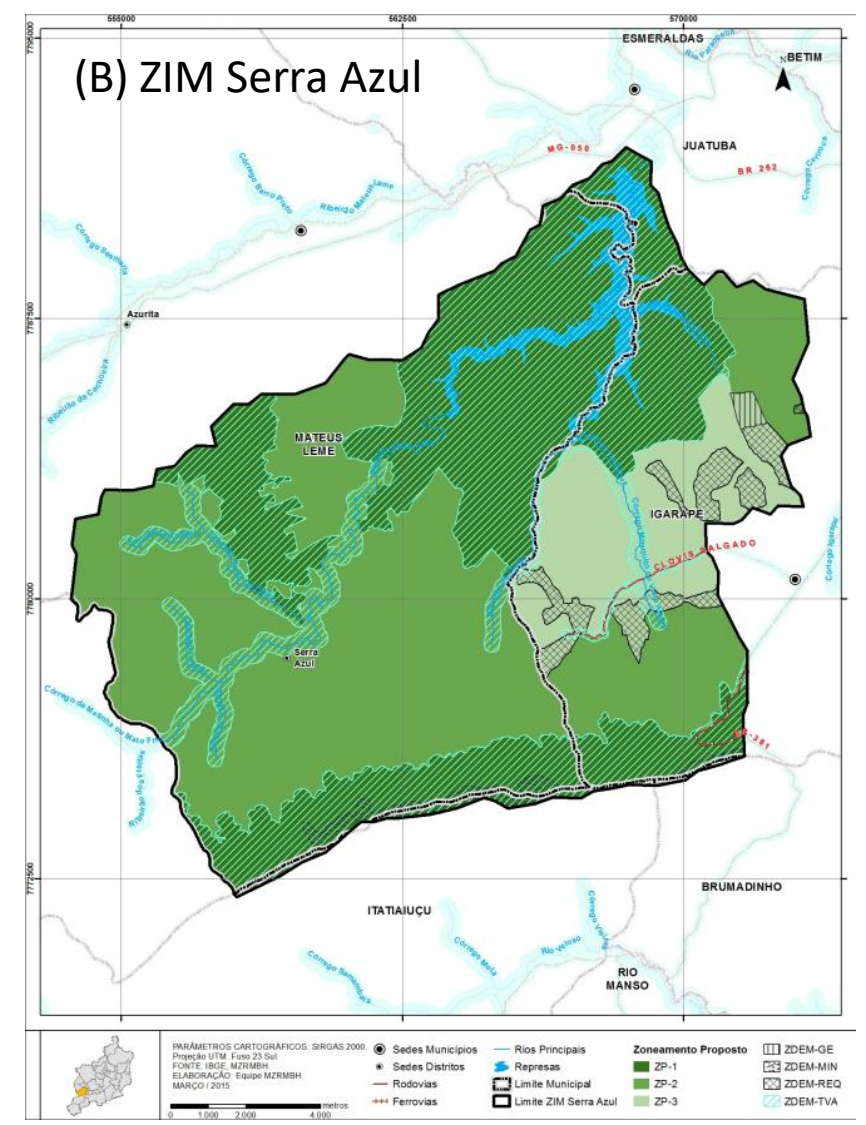

Figure 8. ZIM Serra Azul and its TVA (Source: adapted from UFMG, 2015)

This zoning process also comprises the ZDEM, zones of special metropolitan directives, which are stated as overzoning regulations to meet particular objectives as described below for the ZIM Serra Azul (Figure 8): 
- ZDEM-REQ: focused on the recovery of urban infrastructure and provision of public services at consolidated urban areas to reduce environmental impacts and promote a more diverse land use, including low income housing.

- ZDEM-MIN: focused on mitigating mining impacts and recovering degraded areas.

- ZDEM-GE: focused on mitigating impacts of large urban facilities such as big malls, industrial areas and transport infrastructure, aiming to ensure low environmental impacts, facilitating access and reducing traffic impacts on neighbouring regions.

- ZDEM-TVA: these are the areas that, considering the different objectives and criteria discussed in paragraph 2 above, are defined as part of the metropolitan TVA.

\section{Discussion and conclusion}

The main objective of the ZIM approach is to regulate land use of metropolitan areas which are identified as having primarily metropolitan functions and interests, and for this reason require articulation between regional and local policies when it comes to promoting their development. Considering the difficulties typically observed in Brazil for enforcing municipal land use and environmental regulation, it may be argued that the success of the ZIM approach in the BHMR is possibly compromised. In this case the ZIMs would just become an additional legal layer over the territory with low perspective of being enforced.

Despite recognising this risk, we believe that there are strong arguments to support the hypothesis that the ZIM regulation may be adequately enforced. First, the PDDI and the ZIM proposal were developed under a new and much stronger metropolitan institutional framework, with the support of committees in charge of policy formulation, assessment and accountability, where the diversity of stakeholder interests can be expressed and contribute in the decision-making process. Secondly, the PDDI and ZIM frameworks were constructed under an intense and wide participatory process. The mobilisation of stakeholders supporting a wide range of views and interests in the metropolitan sphere, and the quality of the debates during the planning process are factors that contribute to the political support of the decisions, guidelines and parameters issued from the PDDI and the ZIM formulations. It may also be expected that the materialisation of concepts such as the interconnected multi centres for the metropolitan regions promote their own social and economic dynamics, reinforcing this development trends, provided that public policies on sectors such as housing and transport corroborate those metropolitan policies.

Trade-offs between local and regional interests that underlie the ZIM approach naturally lead to debates around compensating measures. This topic has been part of debates regarding the population living in catchments which are the main sources of drinking water. In the case of the Serra Azul catchment, the large protected area surrounding the reservoir is frequently seen by locals as a restriction for its development. Additionally, many argue that there is a lack of alternatives for leisure and tourism in the metropolitan region and that these protected areas offer unexploited possibilities for ecotourism. If adequately organised, these tourism activities would have a positive local economic impact without compromising the protection of the water sources.

Social acceptability and people involvement are fundamental requirements in the development of a territory, particularly when protecting natural resources is a central goal. Although the ZIM and TVA participatory process was open and had good participation, there were different interest groups that did not participate, either because they were not reached, they did not perceive any advantage to participating, they did not feel represented in the process or they could leverage other political channels. The progressive inclusion of other voices or groups remains a permanent challenge to participation (e.g. Milani, 2006). Financial programs and economic incentives based on politics and detailed technical studies are required to promote the application of land-use restrictions, conciliating and compensating local and regional interests.

Alternatives such as payment for the provision of ecosystem services (e.g. Börner et al, 2010; Chevassus-auLouis, 2009; Grima et al, 2016; Martin-Ortega et al, 2013; Schomers and Matzdorf, 2013; Vatn, 2010) are considered in this debate. Land use restrictions imposed by the ZIM regulation may have negative economic 
impacts on activities such as agriculture, reducing income generation. Furthermore, even when accompanied by environmental protection guidelines, the ZIM regulation will not have a measurable impact on optimising water use for irrigation and may not be sufficient to ensure adequate soil erosion control, for instance. In this sense, the payment for ecosystem services may be a complementary tool to the ZIM approach, helping to maintain local economic activity and to compensate for costs of not complying with environmental legislation (e.g. costs for recovering riparian areas) or to ZIM land use restrictions imposed by the ZIM land use restrictions. It is relevant to highlight that the direct payment for ecosystem services is one way among many to protect water resources. Public policies aiming at enhancing local capacity for adopting more sustainable practices in agriculture, and at the same time promoting the development of markets for organic products with higher added value, may be a way to reach similar objectives. The same can be argued when it comes to promoting rural tourism.

In implementing the ZIM and TVA framework, the public sector plays an important role in supporting transaction costs such as capacity building, development of new technologies, contribution with new market development, and particularly the monitoring and assessing of ZIM and TVA performance. Literature indicates a variety of models regarding institutional arrangements and funding frameworks to promote green strategies (e.g. Rouse and Bunster-Ossa, 2013; The World Bank, 2012; Khan, 2013). In Brazil, the MGSG has a program called "green grant" established by the Minas Gerais Law 17727/2008 (IEF, 2011), which funds farmers to recover and maintain green areas of permanent protection as stated in the Brazilian Forest Code. The national water regulation authority, ANA, also runs a program which funds transaction costs of projects seeking to protect water resources (ANA, 2016). Their funding capacity is minimal with respect to the needs; however they are relevant as demonstration projects.

Regarding the TVA strategy, due to its high attractiveness and acceptance by the civil society and public authorities, it became a central target in the BHMR ZIM planning process. Nevertheless, it is evident that the TVA is a long-term project, which requires different levels of public participation, particularly in a large metropolitan area with more than $10,000 \mathrm{~km}^{2}$ in area and a population of almost 6 million inhabitants. The TVA must be developed with contributions and involvement of many institutions and possibly include a public-private partnership to ensure the required funds promote the diversity of associated economic activities, and at the same time create opportunities for work, income generation and social inclusion.

\section{Acknowledgments}

The authors would like to thank the research funding agencies FAPEMIG, CNPq and CAPES for their financial support to the development of this research. The first, the third and the seventh authors are CNPq fellows under the programme CNPq-PQ.

\section{References}

Allag-Dhuisme, F., Amsallem, J., Barthod, C., Deshayes, M., Graffin, V., Lefeuvre, C., \& Salles E. (2010) Guide méthodologique identifiant les enjeux nationaux et transfrontaliers relatifs à la préservation et à la remise en bon état des continuités écologiques et comportant un volet relatif à l'élaboration des schémas régionaux de cohérence écologique : deuxième document en appui à la mise en oeuvre de la Trame verte et bleue en France. Comité opérationnel 'Trame verte et bleue', MEEDDM, Paris, France

ANA, (2016) Programa Produtor de Água, Agência Nacional de Águas, Brasília, Brasil [online] http://produtordeágua.ana.gov.br (Accessed 28 June 2018)

Baek, S.-S., Choi, D.-H., Jung, J.-W., Lee, H.-J., Lee, H., Yoon, K.-S., Cho, K. H. (2015) 'Optimizing low impact development (LID) for stormwater runoff treatment in urban area, Korea: Experimental and modelling approach'. Water Research, No. 86, pp 122-131

Baptiste, A.K., Foleyb, C., Smardonb, R. (2015) 'Understanding urban neighborhood differences in willingness to implement green infrastructure measures: a case study of Syracuse, NY', Landscape and Urban 
Planning, No. 136, pp 1-12

Bernstein, J.D. (1993) Land use considerations in urban environmental management, The World Bank, Urban Water Management Programme, vol. 12, Washington, USA.

Börner, J., Wunder, S., Wertz-Kanounnikoff S., Rügnitz Tito, M.R., Pereira, L, Nascimento, N. (2010). 'Direct conservation payments in the Brazilian Amazon: Scope and equity implications', Ecological Economics, No. 69 , pp 1272-1282

Bowman, T., Thompson, J., Tyndall, J. (2012) 'Resident, developer, and city staff perceptions of LID and CSD subdivision design approaches', Landscape and Urban Planning, No. 107, pp 43 - 54.

Bowman, T., Thompson, J. (2009) 'Barriers to implementation of low-impact and conservation subdivision design: Developer perceptions and resident demand', Landscape and Urban Planning, No. 92, pp 96 - 105

Brasil, Lei número 12651 de 25 de maio de 2012. Código Florestal (The Forest Code), 38 p.

CERTU (2008) L'Assainissement pluvial integre dans l'aménagement, Éditions du CERTU, Lyon, France

Charlot-Valdieu, C., Outrequin, Ph. (2011) L'urbanisme durable: concevoir un écoquartier, Éditions Le Moniteur, $2^{\text {nd }}$ ed. Paris

Chevassus-au-Louis, B. (Ed.) (2009) Approche économique de la biodiversité et des services liés aux écosystèmes, La Documentation Française. Rapports et Documents No. 18, Paris

Costa, H. S. M., Almeida, D., Melgaço, L., Lara, E., Tupy, I. (2015) 'Urban agriculture and the production of water in the Metropolitan Region of Belo Horioznte (RMBH), Brazil', Proceedings of the UNESCO-ARSEAU Conference "Water, Megacities and Global Change". Unesco and Arseau. Paris, $1^{\text {st }}-4^{\text {th }}$ December 2015, France.

Costa, H.S.M., Nascimento, N.O., Dias, J.B., Welter, M., Nunes Jr., T.T. (2012) 'Urban water management and planning: urban sanitation policies and an emerging institutional structure', International Journal of Water, v. 4, pp 250-269

Costa, G.M., Costa, H.S.M., Dias, J.B., Welter, M. (2009) 'The role of municipal committees in the development of an integrated urban water policy in Belo Horizonte, Brazil', Water Science and Technology, v. 60, 3129-3136.

Farr, D., (2008) Sustainable urbanism: urban design with nature. John Wiley, Hoboken, New Jersey, USA

Fletcher, D., Shuster, W., Hunt, W., Ashley, R., Butler. D., Arthur, S., Trowsdale, S., Barraud, S., SemadeniDavies, A., Bertrand-Krajewski, J.-L., Mikkelsen, P. S., Rivard, G., Uhl, M., Dagenais, D., Vinklander, M. (2014) 'SUDS, LID, BMPs, WSUD and more - the evolution and application of terminology surrounding urban drainage', Urban Water Journal, pp 1-18

Fouchier, V. (1997) Les densités urbaines et le développement durable: Le cas de l'lle-de-France et des Villes Nouvelles. Éditions du SGVN, Paris

Garcia-Cuerva, L., Berglund, E.Z., Rivers III, L. (2018) 'An integrated approach to place Green Infrastructure strategies in marginalized communities and evaluate stormwater mitigation', Journal of Hydrology, No. 559, p. 648-660. 
Grima, N., Singh, S.J., Smetschka, B., Ringhofer, L. (2016) 'Payment for Ecosystem Services (PES) in Latin America: Analysing the Performance of 40 case studies', Ecosystem Services, No. 17, pp 24-32.

IBGE (2014) Anuário Estatístico do Brasil, Instituto Brasileiro de Geografia e Estatística, Rio de Janeiro, Brasil

IEF (2011) Bolsa Verde: manual de princípios, critérios e procedimentos para a implantação da Lei n. 17727 de 13 de agosto de 2008, Minas Gerais, Instituto Estadual de Florestas, Belo Horizonte, Brasil

Jales, L. F. (2013) Modelagem espacial de corredores ecológicos em paisagem naturalmente heterogênea, MSc Thesis, UFMG, Instituto de Ciências Biológicas, Belo Horizonte, Brasil, http://www.bibliotecadigital.ufmg.br/dspace/handle/1843/IGCM-9PBNV8 (Assessed 12 March 2018).

Kelly-Quinn, M., Blacklocke, S., Bruen, M., Earle, R., O'Neill, E., O'Sullivan, J., and Purcell, P. (2014), 'Dublin Ireland: a city addressing challenging water supply, management, and governance issues', Ecology and Society, 19(4): 10 [online], http://dx.doi.org/10.5751/ES-06921-190410 (Assessed 10 July 2018.

Khan, S. (2013) 'Benefits and costs of investing in ecosystems services for clean water supply and flood protection', in Young, M. D. and Esau, C. (Eds.), Investing in water for a green economy: services, infrastructure, policies and management, Routledge, London, pp. 105-118.

Knauer, S.; Nascimento, N. O.; Butterworth, J.; Smits, S.; Lobina, E. (2011) 'Water management and urban planning in Belo Horizonte', in: Butterworth, J.; McIntyre, P.; Wells, C.S. (Eds.), SWITCH in the City: putting water management in test. IRC, The Hague, pp. 111-119

Lundy, L., Wade, R. (2011) 'Integrating science to sustain urban ecosystem services', Progress in Physical Geography, 35(5), pp. 653-669

Martin-Ortega, J., Ojea, E., Roux, C. (2013) 'Payments for Water Ecosystem Services in Latin America: A literature review and conceptual model', Ecosystem Services, No. 6, pp 122-132.

McPherson, G., Simpson, J. R., Peper, P. J., Maco, S. E., Xiao, Q. (2005) 'Municipal forest benefits and costs in five US cities', Journal of Ecology, December 2005, pp. 411-416.

Milani, C.R.S. (2006) 'Le paradoxe du principe participatif dans la gestion publique local', in: Eeuwen, D.V. (Ed), Le nouveau Brésil de Lula, Éditions de l'Aube, La Tour d'Aigues, France, pp. 213-238.

Minas Gerais. Decreto 20792 de 08 de setembro de 1980, APE Mateus Leme, Igarapé e Itauna. 2 p.

Monte-Mór, R.L., Costa, G.M., Costa, H.S.M., Melo, M.G. (2016) 'The university and metropolitan planning: an innovative experience', Nova Economia, Vol. 26, pp. 1133-1156

Meerow, S., Newell, J.P. (2017) 'Spatial planning for multifunctional green infrastructure: Growing resilience in Detroit', Landscape and Urban Planning, No. 159, pp. 62-75

Nascimento, N. O., Heller, L., Knauer, S., Baptista, M. B., Heller, P., Chernicharo, C., Champs, J. R. (2006) Longterm uncertainties and potential risks to urban waters in Belo Horizonte. EU $6^{\text {th }}$ Framework SWITCH Project [online], http://www.switchurbanwater.eu (Assessed in 8 March 2018).

Nascimento, N.O., Vinçon-Leite, B., Gouvello, B., Gutierrez, L., Granceri, M., Silva, T., Costa, H.S.M. (2016) 'Green blue infrastructure at metropolitan scale: a water sustainability approach in the Metropolitan Region of Belo Horizonte, Brazil', in Novatech 2016 Proceedings, Lyon

Neves, B.V.B. (2005) Geoprocessamento como ferramenta no estudo de correlação entre a dinâmica da cobertura vegetal e a evapotranspiração na Bacia do Ribeirão Serra Azul, MG. MSc thesis, UFMG, Escola 
de Engenharia, Belo Horizonte, Brasil. http://www.smarh.ufmg.br/defesas/153M.PDF (Assessed in 8 March 2018).

Niemelä, J., Saarela, S.-R., Söderman, T., Kopperoinen, L., Yli-Pelkone, V., Väre, S., Kotze, D. J. (2010) ‘Using the ecosystem services approach for better planning and conservation of urban green spaces: a Finland case study', Biodiversity Conservation, Vol. 19, pp. 3225-3243

OECD, 2012. Compact city policies: a comparative assessment. OECD Green Growth Studies, OCDE, Paris

Prefeitura de Contagem. (1997) Plano de Desenvolvimento Ambiental de Vargem das Flores, Prefeitura de Contagem, PROSAM, Contagem, Brasil

Romnée, A., Evrard, A., Trachte, S. (2015) 'Methodology for a stormwater sensitive urban watershed design', Journal of Hydrology, No. 530, pp. 87-102.

Rouse, D. C., Bunster-Ossa, I. F. (2013) Green Infrastructure: a landscape approach. American Planning Association, Planning Advisory Service, Report Number 571, Chicago, USA

Schomers, S., Matzdorf, B. (2013) 'Payments for ecosystem services: A review and comparison of developing and industrialized countries', Ecosystem Services, No. 6, pp 16-30

UFMG, PUC Minas, UEMG (2011) Plano Diretor de Desenvolvimento Integrado da RMBH (PDDI), [online], UFMG, Belo Horizonte, Brasil, http://www.rmbh.org.br (Assessed 5 March 2018)

UFMG (2015) Plano Diretor de Desenvolvimento Integrado da RMBH - Macrozoneamento RMBH. UFMG, vol. 5, Belo Horizonte, Brasil, http://www.rmbh.org.br (Assessed 5 March 2018)

Vatn, A. (2010) 'An institutional analysis of payments for environmental services', Ecological Economics, No. 69, pp $1245-1252$

Vimal, R., Mathevet, R., Michel, L. (2012) 'Entre expertises et jeux d'acteurs : la trame verte et bleue du Grenelle de l'environnement', Natures Sciences Sociétés, 20(4), pp 415-424.

The World Bank. (2012) Green infrastructure finance, The World Bank Study, Framework Report. Washington, USA

Zhang, K. and Chui, T.F.M. (2018) 'A comprehensive review of spatial allocation of LID-BMP-GI practices: Strategies and optimization tools', Science of the Total Environment, No. 621, pp 915-929 